\title{
A New Source for the Vita Æ\&wardi regis
}

\author{
TOM LICENCE \\ University of East Anglia
}

\section{Introduction}

Of the passages in the Vita Ædwardi regis (hereafter the Vita) which have attracted scholarly interest, one of the most detailed was described by its editor, Frank Barlow, as "a lengthy, somewhat irrelevant, and certainly disproportionate account of the large English legation to the papal curia, led by Earl Tostig, in 1061." Its business included the acquisition of a pallium for the new archbishop of York, Ealdred (1061-1069), the resolution of a dispute between York and the bishopric of Dorchester over the province of Lindsey, and the objectives of two new bishops, Giso of Wells and Walter of Hereford, to seek consecration (and privileges) from the pope in person. The legation, however, suffered humiliating setbacks in failing to secure the pallium and falling prey to bandits when leaving Rome. ${ }^{2}$ Barlow deemed the Vita's detailed account "somewhat irrelevant" because it had nothing to do with King Edward, and "disproportionate" because of the excessive attention it pays to the legation. ${ }^{3}$ The identification of an unnoticed source for the account sheds light on its purpose and shows how the author rewrote his sources.

The source in question is a letter or privilege of 1061 from Pope Nicholas II to Ealdred. It survives in the form of two independent copies, entered into two fourteenth-century registers, concerning and emanating from the archdiocese of York. One copy is preserved in the York cartulary, now London, British Library, MS Lansdowne 402, fol. 29rv. The other is found in York, D \& C, i (a compendium known as the Magnum Registrum Album), at fols. 40-41. It was printed, without reference to the

\footnotetext{
${ }^{1}$ Vita Adwardi regis qui apud Westmonasterium requiescit: The Life of King Edward who Rests at Westminster, ed. and trans. Frank Barlow, 2nd ed. (Oxford, 1992), pp. lix, 52-56.

${ }^{2}$ Edward referred the Lindsey dispute to the pope. For the details, see Stephen Baxter, "The Death of Burgheard Son of Ælfgar and Its Context," in Frankland: The Franks and the World of the Early Middle Ages: Essays in Honour of Dame Jinty Nelson, ed. Paul Fouracre and David Ganz (Manchester - New York, 2008), pp. 266-84, at 280-84. For the 1061 legation and Pope Nicholas's response, see Francesca Tinti, "The pallium Privilege of Pope Nicholas II for Archbishop Ealdred of York (AD 1061)" (forthcoming). I am grateful to Dr. Tinti for allowing me to consult her article prior to publication and for commenting on an earlier draft of mine.

${ }^{3}$ The brief he outlines at the start of his work is to relate the deeds of Edward, Edith, Harold, and Tostig: Vita Ædwardi, ed. Barlow, pp. 6/7-8/9.
} 
1 Lansdowne manuscript, in the York compilation in the Rolls Series. ${ }^{4}$ While my article 2 was in progress, Francesca Tinti was preparing an edition of the letter. Unaware, at the 3 time, that we were collating the textual witnesses independently, we were subse4 quently able to check each other's readings. Previous inquirers have delivered no ver5 dict on the missive, suspicious of its narrative detail, which is uncommon in papal let6 ters. Tinti, finding comparison points in other papal privileges, defends its authentic7 ity, and I take the same line while proposing that the narrative in the papal letter was a 8 direct textual source for the Vita's account of the legation of 1061 . The authenticity of 9 the letter is thus reinforced from a new angle, since the Vita was written ca. 1066.

I argued in a recent article that Barlow's case for placing the composition of the Vita at Canterbury is shaky and that a better case can be made for linking it (or its author at least) to York. Points in favour of this case are as follows. The author took an interest in Tostig, who, as Barlow noted, "would appear to have been ... the writer's favourite," and whom "he follows more closely than Harold." Although his interest might reflect the preference of his patron Queen Edith for Tostig over Harold, her other brother, it is also what might be expected in the work of a writer based in Tostig's earldom, which centred around York. The writer took an admiring interest in Tostig's predecessor, Earl Siward (d. 1055). ${ }^{6}$ In several passages, he mentions churches or monasteries and specifies their location, although all would have been familiar to his readers. He mentions "the monastery they call the Old Minster at Winchester," "the Church of Christ at Canterbury," "that same Church of Christ" (naming Canterbury in the previous sentence), "the monastery at Glastonbury," "the monastery at Wilton" (four times), and "St Peter's monastery, outside the walls of London, on the Thames" (i.e. Westminster). ${ }^{7}$ The sole exception is his reference to "the church ... of St Olave, king and martyr" which was Siward's foundation and burial place. From a courtly perspective, this would have been the most obscure church he identified, partly because it was a recent foundation, partly because the circuit in which the king moved did not extend into Yorkshire. Yet the writer omitted to men-

${ }^{4}$ Jaffé-Loewenfeld 4463. Magnum Registrum Album, York, York D \& C, i, fols. 40-41; printed in The Historians of the Church of York and Its Archbishops, ed. James Raine, 3 vols., Rolls Series 71 (London, 1879-1894), 3:5-7. A second copy is preserved in another fourteenth-century cartulary from York, now London, British Library, MS Lansdowne 402, fol. 29rv. I will refer to the text from the Magnum Registrum Album as $\mathbf{A}$, and to the Lansdowne text as $\mathbf{B}$.

${ }^{5}$ Vita Ædwardi, ed. Barlow, pp. xxiii, xlvi.

${ }^{6}$ Tom Licence, “The Date and Authorship of the Vita Edwardi regis," Anglo-Saxon England 44 (2016), 259-85, at p. 274.

${ }^{7}$ Vita Ædwardi, ed. Barlow, p. 46 (Winchester), pp. 14 and 30 (Canterbury), p. 14 (Glastonbury), pp. 36, 44 and 70 (Wilton), and p. 66 (Westminster). 
1 tion that it was situated in York. ${ }^{8}$ This is the sort of oversight that is born of familiarity, when a writer forgets that what is obvious to him might not be to his readers.

Building on such points as were made in my earlier article we can add the evidence that the two most detailed passages in the Vita, apart from the eyewitness description of the work in progress at Westminster, are the account of the legation to Rome in 1061 and the account of the northern rebellion in $1065 .{ }^{9}$ Both are concerned with the affairs of the chief men (and women) of the northern earldom, principally Ealdred, Tostig and, to a lesser extent, his wife Judith and a deputy, Gospatric. To this catalogue can now be added the thesis that the author consulted a papal letter addressed to Ealdred, which is not known to have circulated beyond York, and which contained personal admonitions which Ealdred might have preferred not to broadcast. ${ }^{10}$

\section{Folcard's Authorship and Rewriting Techniques}

13 In the article previously mentioned, I used the hypothesized York connexion, along with authorial idiosyncrasies, to attribute the anonymous Vita to Folcard of St. Bertin. Folcard (fl. 1060s) was one of two monks from the Flemish abbey of St. Bertin who were living in England about that time and who are known to have written hagiographical works, the other being Goscelin. As such, these two men were the candidates Barlow proposed as possible authors of the Vita, on account of the text's Latin style and its interest in Flanders. Goscelin has since been dismissed as an authorial contender, and no other candidate has emerged to rival Folcard. ${ }^{11}$ Barlow favoured Folcard's candidacy. ${ }^{12}$ Without picking up on a York link in the Vita, he also demonstrated in his discussion of the different contenders that Folcard was active in York at the right time. As Barlow noted, Folcard prepared a Life of St. John of Bever-

${ }^{8}$ Vita Ædwardi, ed. Barlow, pp. 46-48; Licence, “The Date and Authorship,” p. 274

${ }^{9}$ Vita Ædwardi, ed. Barlow, pp.52-56 (Rome mission); pp. 76-80 (northern rebellion); see also pp. 66-70 (Westminster).

${ }^{10}$ I am grateful to Dr. Tinti (personal communication) for affirming my opinion that the content of the letter was sensitive.

${ }^{11}$ See Licence, "The Date and Authorship," pp. 273-85, and Tyler's response, in Elizabeth M. Tyler, England in Europe: English Royal Women and Literary Patronage, c. 1000-c. 1150 (Toronto, 2017), pp. 248-52. The author cannot be Bishop Herman of Ramsbury-Sherborne-Old Sarum (1045-1055, 1058-1078) as Tyler suggests as a possibility on pp. 252-53, because the anonymous indicates that he did not have firsthand knowledge of Robert of Jumièges (archbishop of Canterbury 1051-1052/5); Herman would have known much about the king's exile and early years, whereas the Vita IJdwardi, ed. Barlow, p. 28.24, uses the pharase "ut aiunt." On p. 251, she notes that there is a strong case for associating the anonymous with the abbey of St. Bertin. Once Bishop Herman is eliminated, we are left with Folcard and Goscelin, whose candidature experts now discredit (Tyler, England in Europe, p. 248).

${ }^{12}$ Vita $Æ d w a r d i$, ed. Barlow, p. lix: "Folcard, on the other hand [viz. as opposed to Goscelin], seems to suit the immediate requirements much more closely." 
1 ley by rewriting Bede's account of the saint. He wrote it for Ealdred, John's distant 2 successor in the see. He states in the preface that the queen, who could only have been 3 Edith, wife of Edward the Confessor (who reigned until 1066), had sent him with an 4 escort to Ealdred, whose acquaintance he had already made, and that he wrote the 5 text and Responsories for the saint's feast for the archbishop. ${ }^{13}$ The date of the work 6 must lie between 1061 and 1066, and it shows that Folcard was active in York, in 7 Ealdred's household, shortly before or about the time the Vita was written. In this 8 context it is no surprise to find that the author of the Vita took an interest in Ealdred's 9 adventures in Rome and was able to consult the papal letter, which is not known to 10 have circulated beyond York.

As I will show in this article, Folcard's account in the Vita, concerning the 1061 legation to Rome, revises and amplifies the account given in the letter. My objective is to demonstrate a direct relationship between the two by disposing of the alternative hypothesis that there was a common (or intermediary) source now presumed lost, and also by banishing the hypothesis that the letter and the Vita are entirely independent accounts. Though it is clear that each has information the other lacks, it should also become evident in the light of the argument below that the Vita adopts the narrative structure and content of the letter. It is useful to imagine the author, Folcard, drawing on the letter for convenience, as providing a basic outline of events, but shifting the emphasis here and there and including additional detail, which he could have learned from Ealdred himself or his companions on the journey to Rome. Those companions would have included members of Ealdred's household - the very men Folcard was mingling with in Yorkshire.

First, a few words on rewriting are in order, since the ways in which texts were rewritten could be as various as the motives for rewriting them. Even when the motives they expressed, which conventionally aspire to stylistic improvement, were similar, writers adopted different approaches when rewriting other writers' texts. ${ }^{14}$ By far the commonest technique, and least interventionist, was to retain much of the wording and word order of the parent work, while excising or inserting text where appropriate. The three Lives of St. Ecgwine of Evesham: i.e. Byrhtferth's Life of ca. 1000, the "Digby-Gotha recension," and Dominic of Evesham's Life, offer a case in point, irrespective of debate about which of the last two has priority, for each one preserves whole phrases and passages from its predecessor. ${ }^{15}$ When Ælfric of Eynsham, ca. 1006, prepared an abridgement of the Life of St. Swithun, written a decade earlier

\footnotetext{
${ }^{13}$ For Barlow's groundwork, see Vita ÆEdwardi, ed. Barlow, pp. lii-lvi.

${ }^{14}$ Monique Goullet, Écriture et réécriture hagiographiques: Essai sur les réécritures de Vies de saints dans l'Occident latin médiéval (VIII $-X I I^{e}$ s.) (Turnhout, 2005), pp. 31-58.

${ }^{15}$ Samuel O’Rourke, "Hagiography and Exemption at Medieval Eynsham, 1000-1250: The Evidence of the Vitae Ecgwini,” Mediaeval Studies 75 (2013), 271-306.
} 
1 by the monk Wulfstan of Winchester, he aimed at simplicity and clarity, though not to 2 the extent that he rewrote the text. For the most part, he merely removed superfluous 3 detail. Only on rare occasions did he replace a word, substituting saepe for frequenter 4 in one instance; eius for illius; tunc for autem, and anaphas (cup) for calix (chalice), 5 which Wulfstan had used inappropriately in a non-liturgical context. ${ }^{16} \mathrm{On}$ a rough 6 count, more than $80 \%$ of Ælfric's words are Wulfstan's, a fact which ensures that even 7 an untrained eye will be able to detect derivation (if not which has priority) by the 8 method of comparing parallel passages.

To take another example: the late twelfth-century author, conveniently known as "Samson," who recast Goscelin's Miracles of St. Edmund (itself a reworking of Herman's Miracles), sought not only to simplify, but also to eliminate internal rhyme, dilute heady rhetoric, and replace obscure or frilly words with plainer synonyms; he did not take the trouble of rewriting the text. ${ }^{17}$ Folcard's contemporary, Sigebert of Gembloux (1028-1112), prioritized elegance, clarity, and spaciousness of prose when rewriting; and, if they adorned an idea, he was not averse to substituting the sort of rare words habitually removed by Ælfric and "Samson." ${ }^{18}$ Goscelin of St. Bertin (fl. 1060s-1100s) engaged closely with his material, thoroughly rewriting it while adding colour, personal reflections, and scriptural reference points; he rather liked ornate vocabulary. ${ }^{19}$ Folcard too was unusual in that he rewrote his material thoroughly; but while he was content to rearrange it and amplify the detail in ways which improved the story, he indulged less in the dramatic crafts of storytelling with its suspense and resolution, captivating devices and urbane asides. Folcard did employ rhetoric on the right occasion, but alongside Goscelin's narratives his prose is plainer and more succinct.

In Raine's edition of Folcard's Life of St. John of Beverley the fourth to eighth chapters constitute a rewriting of the miracles of St. John described in the second to

\footnotetext{
${ }^{16}$ Wulfstan of Winchester, Life of St Æthelwold, ed. Michael Lapidge and Michael Winterbottom (Oxford, 1991), pp.cl-clv (with illius/eius and autem/tunc on p.cli); A.G. Rigg, "The Long or the Short of It? Amplification or Abbreviation,” The Journal of Medieval Latin 10 (2000), 46-73, at pp. 6567.

${ }^{17}$ Rodney M. Thomson, “Two Versions of a Saint's Life from St Edmund's Abbey. Changing Currents in XII ${ }^{\text {th }}$-century Monastic Style,” Revue bénédictine 84 (1974), 383-408, at pp. 394-96.

${ }^{18}$ Goullet, Écriture, pp. 135-37; see Tom Licence, "New Light on the Life and Work of Herman the Archdeacon," in Bury St Edmunds and the Norman Conquest, ed. Tom Licence (Woodbridge, 2014), pp. 94-103, at 95-97.

${ }^{19}$ Compare, for example, Herman and Goscelin's accounts of the miracle involving Osgod Clapa, in Herman the Archdeacon and Goscelin of Saint-Bertin, Miracles of St Edmund, ed. Tom Licence (Oxford, 2014), pp. 54-58 and 206-10; and for his word-hoard, see Thomas J. Hamilton, "Goscelin of Canterbury: A Critical Study of His Life, Works, and Accomplishments” (Ph.D. diss., University of Virginia, 1973), pp. 380-84.
} 
1 sixth chapters of the fifth book of Bede's Ecclesiastical History. ${ }^{20}$ Comparing parallel 2 passages allows us to observe Folcard's manner of rewriting. In this case, however, it is 3 important to remark that the events described by Bede, if at all real, had happened 4 long ago, and that Folcard seems to have had no new information to work into the 5 narrative (as he should have had when basing his account of the legation to Rome on 6 Nicholas's letter). It is also salient that Folcard's revision of Bede's text was less politi7 cal, in that he had no particular bone to pick with Bede, whereas he did - if my argu8 ment is accepted - have a "spin" to put upon the papal story in Ealdred's letter. We 9 shall come to that presently. Bearing all this in mind, we might expect Folcard's 10 rewriting of Bede's text of St. John to add fewer "facts" to the parent account than his rewriting of the papal letter, and to be less concerned with putting his own political perspective on it, not counting his own, occasional exegetical insights and the little links that help to smooth the narrative. Indeed, this is how his rewriting of Bede's work behaves.

We can also use Folcard's Life of St. John as a sample to establish his thoroughness of rephrasing, if only in this case. That is to say we can work out how often he retained Bede's lexical units. For the purpose of this exercise, lexical unit means a word, word stem or small word chain, no matter the order the words appear. To cite all the examples: ${ }^{21}$ Folcard's Life of St. John preserves 44 lexical units from Bede (not counting proper nouns) in 828 words of reworked Bedan material from the relevant chapters in Bede's Ecclesiastical History. ${ }^{22}$ These comprise 55 reiterated words and word stems. If

${ }^{20}$ Vita sancti Johannis episcopi Eboracensis (scil. Johannes Beuerlacensis), in Historians of the Church of York and Its Archbishops, ed. James Raine the younger, Rolls Series 71, 3 vols. (1879-1894), 1:239-60, at pp. 246-52; Bede's Ecclesiastical History of the English People, ed. Bertram Colgrave and Roger A.B. Mynors (Oxford, 1969), pp. 456/7-468/9.

${ }^{21}$ The references to Vita sancti Johannis episcopi Eboracensis (scil. Beuerlacensis) (hereafter VJB) are to the chapter and line number respectively, in Raine's edition (with lines being numbered by chapter, not by page). The references to Bede's Historia Ecclesiastica (hereafter HE) are to the book, chapter, and line number respectively (with lines again being numbered by chapter, not by page).

${ }^{22}$ The 44 I identify are: non longe (VJB 4.13; HE v.2.9); amne (VJB 4.13; HE v.2.10); et maxime (VJB 4.14; HE v.2.12); orationibus (VJB 4.16; HE v.2.13); manebat (VJB 4.17; HE v.2.13: manere); cum quodam tempore (VJB 4.17-18; HE v.2.14: cumque tempore quodam); iussisset (VJB 4.19; HE v.2.15: iussit); mutus erat (VJB 4.20; HE v.2.18-19: erat ... mutus); nouerat (VJB 4.24; HE v.2.19: notus); mento (VJB 4.28; HE v.2.29); loqueretur praecipit (VJB 4.29; HE v.2.31: loqui .. praecepit); dicendo (VJB 4.30; HE v.2.31: dicito); uerba (VJB 4.30; HE v.2.31: uerbum); literas (VJB 4.30; HE v.2.34: litterarum); soluto linguae (VJB 4.31; HE v.2.33); sententias (VJB 4.33; HE v.2.38); capitis (VJB 4.35; HE v.2.47); crispo (VJB 4.36; HE v.2.51: crispis); tempore (VJB 5.1; HE v.3.5); monasterium (VJB 5.2; HE v.3.6); praeerat (VJB 5.3; HE v.3.7: praefuit); melius (VJB 5.11; HE v.3.17); in quarta luna (VJB 5.13; HE v.3.19: in luna quarta); memoratque (VJB 5.16; HE v.3.21: memini); periculosissimam esse (VJB 5.18; HE v.3.22: periculosa sit); lunae (VJB 5.20; HE v.3.23); rheumate (VJB 5.21; HE v.3.23: reuma); intrat (VJB 5.23; HE v.3.27: intrauit); orationis (VJB 5.25; HE v.3.29: orationem); dedicandam (VJB 6.1-2 and 18; 
1 we take those words and word stems as a fraction of the sample (55/828) and convert

2 the fraction into a percentage, we arrive at $6.6 \%$ - a rough but useful indication of the

3 percentage of words/word stems which Folcard retained from a source he was

4 rewriting. Since his basic approach to rewriting is unlikely to have changed very much

5 when he was simply about the business of putting source text into his own words

6 (rather than adding lengthy interpolations, say), we might expect a similarly low

7 percentage of words to be retained in his other rewritings, where the rewritten

8 passages can be compared to the parent text. It is important, in any case, to identify

9 where reworking ends and interpolation begins. A premise of the argument that

10 follows is that some parts of the Vita's account of the legation to Rome are reworkings

11 of passages in the letter, and that other parts represent insertions of original matter

12 into the narrative framework it proffered. The best example is the paragraph

13 describing the adventures of Earl Tostig and his deputy Gospatric during the bandit

14 attack as the party were leaving Rome. The letter refers to that attack briefly in vague

15 terms. The Vita (at the same juncture as the letter) supplies exciting details. Without

16 disrupting the skeleton structure of the narrative in the letter, Folcard was fleshing out

17 the story. At that point he stopped reworking and began interpolating. Having added

18 his new matter, he resumed the convenience of reworking the source in front of him.

\section{Folcard and His Source: A Comparison}

20 It is time now to consider the letter's account and the Vita's account in parallel. Below, 21 corresponding passages of Latin are set out side by side, each with an English transla22 tion. I have broken up the narrative that both sources share into five artificial sections, 23 not only for ease of analysis, but also to reveal that the framework of both is the same. 24 When two people narrate complex events independently there is infinite room for 25 variation in what they elect to recount and how they devise to put together the story. When, however, one person derives his version from another, a similar narrative framework and devices may occur. The opening argument against the hypothesis that the two accounts are independent is their commonality of design. They share too many narrative "stepping stones" and choices of what to emphasize en route for their respective narrators to have advanced down paths so similar coincidentally. In

HE v.4.7 and 18: dedicationem, counted twice); domum (VJB 6.6; HE v.4.9); instabat (VJB 6.6; HE v.4.11: instans); prandium (VJB 6.7; HE v.4.8-9: ad prandendum); diceret (VJB 6.8; HE v.4.9: dicens); promissis ... eleemosynis (VJB 6.11; HE v.4.13-14: promittens ... elimosynas); consecratis (VJB 6.18; HE v.4.18: consecrauerat); dolor (VJB 6.19; HE v.4.20: dolorem); facto (VJB 6.20; HE v.4.21: factum); surgit (VJB 6.22; HE v.4.27: surrexit); socrum (VJB 6.30; HE v.4.25); mittit (VJB 7.16; HE v.5.15: misit); sibi mittat (VJB 7.17-18; HE v.5.15-16: sibi ... mittere), and conuiuantes (VJB 7.22; HE v.5.20: conuiuas). The sample comprises VJB chapters 4 (lines 11-30), 5 (lines 1-38), 6 (lines 1-34), and 7 (lines 1-28) on pp. 246-51, amounting to 828 words. 
1 presenting the texts below, I have only included the passages that are in dialogue 2 that is, where Folcard was reworking his source (putting text into his own words). 3 Where he simply omitted portions of the narrative, they are outlined in brackets, as 4 are the insertions he made himself. With those passages removed, the common struc5 ture comes more clearly into view. Nicholas's text, written in the first person and pre6 sented in the left column, is referred to as $\mathbf{N}$. The Vita's text, $\mathbf{V}$, appears in the right 7 column. I have numbered the artificial sections of the narrative and summarized each, 8 prior to the parallel text, to highlight the "stepping stones" the accounts have in com9 mon. To reconstruct the original text of $\mathbf{N}$, I have compared the copy of the letter in $\mathbf{A}$ 10 (the Magnum Registrum Album) with the copy in B (London, British Library, MS 11 Landsdowne 402). Where variations occur, my preferred reading is included below, and the rejected reading from either $\mathbf{A}$ or $\mathbf{B}$ is given in a footnote.

(i) Ealdred, seeking the pallium, is found to have transferred from one see to another without the pope's permission:

\begin{tabular}{|c|c|}
\hline $\begin{array}{l}\text { Quocirca, }{ }^{25} \text { congregatis quamplurimis con- } \\
\text { fratribus coepiscopis nostris, Romano }^{26} \text { sy- } \\
\text { nodo }^{27} \text { presidentes, atque de }{ }^{28} \text { ecclesiasticis }^{29} \text { uniuersali- } \\
\text { utilitatibus tum generaliter tum }{ }^{29} \text { te karissime } \\
\text { ter cum eis tractantes, dum ad te ke } \\
\text { confrater }{ }^{30} \text { [sc. Ealdred] uentum esset, quia } \\
\text { te de sede ad sedem sine apostolica aucto- } \\
\text { ritate }^{31} \text { migrasse comperimus, }\end{array}$ & $\begin{array}{l}\text { Perscrutatus ergo qualiter ad sacros acces- } \\
\text { sisset ordines, eo gratuito confitente, inuen- } \\
\text { tus est a primo ordinationis suę episcopio ad } \\
\text { aliud commigrasse contra canones. }\end{array}$ \\
\hline $\begin{array}{l}\text { When we were presiding at the Roman } \\
\text { synod where many of our fellow brother } \\
\text { bishops had assembled, and discussing } \\
\text { ecclesiastical policies with them collectively }\end{array}$ & $\begin{array}{l}\text { On being questioned about how he had come } \\
\text { to sacred orders, and, with he himself freely } \\
\text { admitting it, he was found to have transferred } \\
\text { from the first bishopric to which he was ap- }\end{array}$ \\
\hline
\end{tabular}

${ }^{23}$ Printed, from A only, in Historians, ed. Raine, 3:6. New edition by Tinti (forthcoming; see above, n. 2).

${ }^{24}$ Vita Ædwardi, ed. Barlow, pp. 54-56.

25 “Quocirca” begins a sentence in $\mathbf{B}$, less clearly in A, but not in Raine's transcription of $\mathbf{A}$.

${ }^{26}$ Romano] Romane A

${ }^{27}$ synodo] sinodo $\mathbf{A}$

$\left.{ }^{28} \mathrm{de}\right]$ om. $\mathbf{A}$

${ }^{29}$ tum] cum $\mathbf{A}$

${ }^{30}$ karissime confrater] frater karissime $\mathbf{B}$

${ }^{31}$ apostolica auctoritate] auctoritate apostolica B 
and individually, your case was discussed, dear brother; and because we discovered that you had transferred from see to see without papal permission, pointed to another, against canon law.

(ii) Nicholas therefore deprived him of episcopal office:

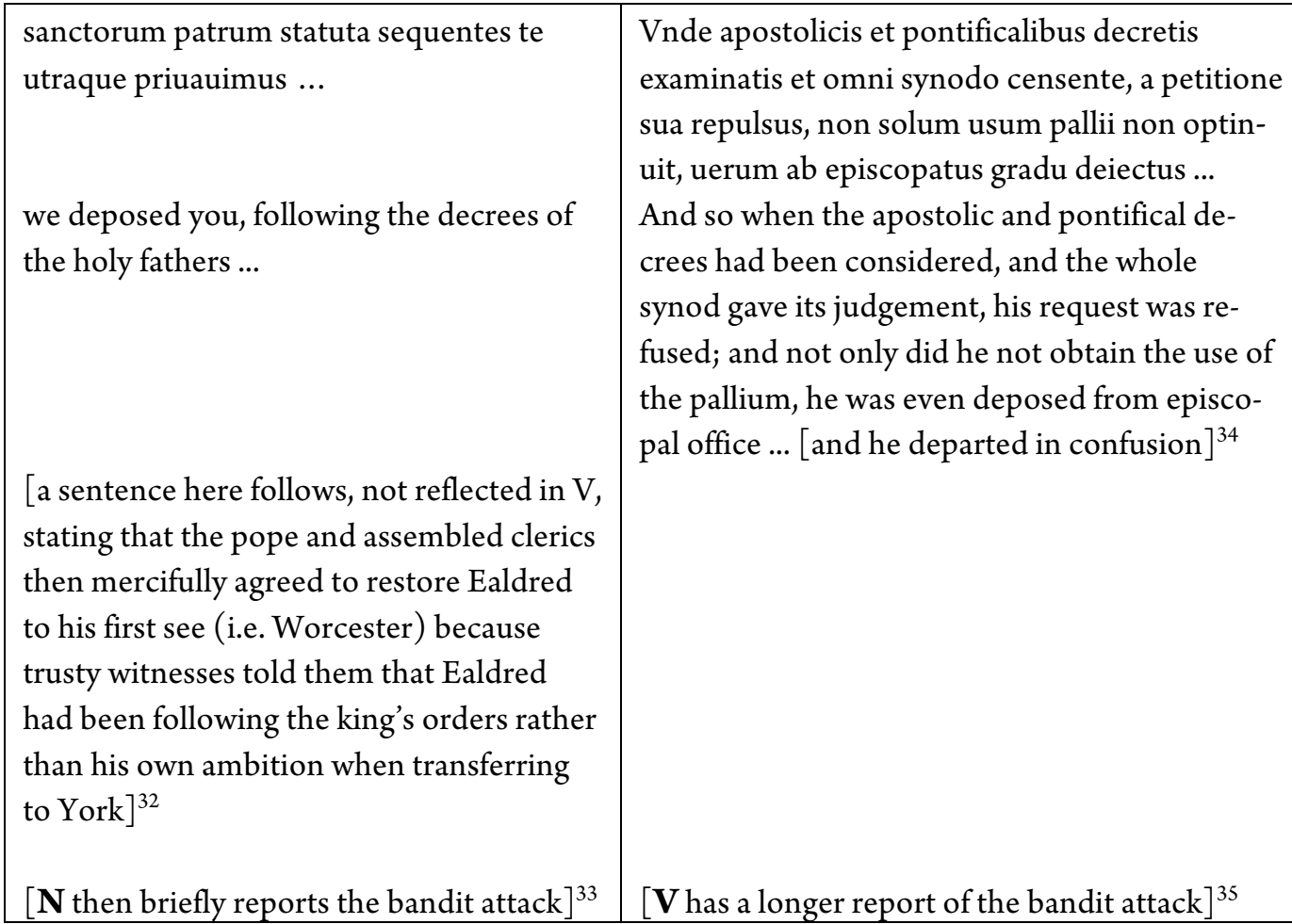

32 "sed quia hoc te non ambitione sed iussione filii nostri regis coactum fecisse idoneis testibus in eodem sinodo comprobavimus, interuentu omnium confratrum nostrorum episcoporum, priori te postmodum sedi, misericorditer restituimus" - "but since we proved in the same synod, by [the evidence of] suitable witnesses, that you were compelled to do this not by ambition but by the order of our son, the king, we mercifully reinstated you in your former see, at the petition of all our brother bishops."

33 "Quibus ita peractis, dum inimici Dei Omnipotentis et Sancti Petri apostolorum principis te de seruitio eius reuertentem in itinere ceperunt, et ablatis omnibus quae habebas, uulneratisque tuis et caesis, nimis te crudeliter tractauerunt" - "This business had only just concluded when enemies of Almighty God and St. Peter, Prince of the Apostles, captured you on the journey back from doing his bidding and treated you most cruelly, having robbed you of everything you had and having wounded and killed your men."

34 "in hac confusione recedere habuit" - "and he had to leave in this confusion."

${ }^{35}$ V's account of the attack occupies pp. 54-56 of Barlow's edition. 
1 (iii) Ealdred's party returns to Rome after the attack and is received by the pope and 2 clergy with empathy:

\begin{tabular}{|l|l|}
\hline $\begin{array}{l}\text { Tuis cum omnibus Romane ecclesie filiis } \\
\text { precordialiter calamitatibus condolentes, } \\
\text { et ut multiplicem angustiam tribulationis } \\
\text { tue consolaremur }{ }^{36} \text { ad hoc quod nullis } \\
\text { unquam }^{37} \text { precibus uel pretiis }^{38} \text { flecti } \\
\text { potuimus, }\end{array}$ & $\begin{array}{l}\text { Confuse ergo et miserabiliter reuersis Romana } \\
\text { pietas indoluit, ueritusque domnus papa maxi- } \\
\text { me clarissimi ducis petitionem, presertim et re- } \\
\text { memorans gratuitam episcopi confessionem, et } \\
\text { eam quam sibi intulerant in degradatione } \\
\text { humiliter susceptam confusionem, }\end{array}$ \\
$\begin{array}{l}\text { Feeling, with all the sons of the Roman [Ealdred] returned in confusion and } \\
\text { Church, the pangs of your misfortunes, } \\
\text { and wishing that we might soothe the } \\
\text { complex impasse of your distress, what no } \\
\text { prayers or payments could bend us to } \\
\text { grant, }\end{array}$ & $\begin{array}{l}\text { pope, respecting above all the petition of the } \\
\text { most famous earl [Tostig], and calling to mind } \\
\text { especially the bishop's free confession and his } \\
\text { humbly borne shame (which they had brought } \\
\text { upon themselves by deposing him), and }\end{array}$ \\
\hline
\end{tabular}

3 (iv) The pope now bends to lobbying on Ealdred's behalf and grants him the pallium:

\begin{tabular}{|l|l|}
\hline $\begin{array}{l}\text { condescendentes supplicationem omnium } \\
\text { cardinalium confratrum ac filiorum } \\
\text { nostrorum episcoporum uidelicet ac } \\
\text { presbyterorum ac } \mathrm{c}^{39} \text { specialiter } \mathrm{ac}^{40} \text { prae- }^{41}\end{array}$ & $\begin{array}{l}\text { consultus a Romanis patribus ne et depredatę } \\
\text { et insuper confuse a beati Petri pietate specta- } \\
\text { biles personę in tanto recederent merore, letifi- } \\
\text { archidiaconi, dilectioni tuae karissime } \\
\text { caumnes in episcopi reconciliatione et dato } \\
\text { pallii honore, }\end{array}$ \\
$\begin{array}{l}\text { ad hoc concedimus, } \\
\text { yielding to the petition of all our brother } \\
\text { cardinals and sons, the bishops and } \\
\text { priests, foremost and especially our most }\end{array}$ & $\begin{array}{l}\text { advised by the Roman fathers that eminent } \\
\text { persons should not depart from the pity of } \\
\text { St. Peter in such distress, both pillaged and }\end{array}$ \\
\hline
\end{tabular}

${ }^{36}$ consolaremur] consolaretur B

${ }^{37}$ unquam] umquam $\mathbf{B}$

${ }^{38}$ pretiis] preciis $\mathbf{B}$

$\left.{ }^{39} \mathrm{ac}\right]$ et $\mathbf{B}$

$\left.{ }^{40} \mathrm{ac}\right]$ et $\mathbf{B}$

${ }^{41}$ Heldebrandi] Heldeprandi A

${ }^{42}$ dignitatis] om. A 
dear son Archdeacon Hildebrand, to your delight, dear brother, we granted, the pallium of pontifical office for the reason dismayed, gladdened everyone by reinstating the bishop and granting him the honour of the pallium,

1 (v) That devotion may increase among his people:

\begin{tabular}{l|l}
$\begin{array}{l}\text { ut quod specie gestaueris, moribus pre- } \\
\text { tendas, et quod }{ }^{43} \text { prefulget in habitu, } \\
\text { subiectis tibi }{ }^{45} \text { gregibus religiose uite ac } \\
\text { salutaris doctrinae factis pariter et dictis } \\
\text { ostendas. }\end{array}$ & $\begin{array}{l}\text { ut scilicet in regno suo in eiusdem apostoli per- } \\
\text { sisterent ampliori fidelitate et ueneratione. }\end{array}$ \\
$\begin{array}{l}\text { that your conduct may justify the splen- } \\
\text { dour you wear, and that you may exem- } \\
\text { plify what shines forth from your garment } \\
\text { to the flocks in your care as much by the } \\
\text { deeds of a religious life as by words of } \\
\text { wholesome teaching. }\end{array}$ & $\begin{array}{l}\text { so that [the people of] his kingdom would } \\
\text { persevere in greater fidelity and worship of that } \\
\text { apostle. }\end{array}$ \\
\hline
\end{tabular}

\section{Discussion of the Two Accounts}

3 Proceeding from the obvious point that the accounts outline the same events, we 4 should consider what might be revealed by their difference of emphasis. $\mathbf{N}$, for its part, 5 consistently emphasizes the agency of the pope and his supporting clergy, as might be 6 expected in a papal letter. Written in Pope Nicholas's voice in the first-person plural, it 7 presents him always as the agent. Nicholas is the one examining (tractantes) cases, 8 including that of Ealdred; it is he who finds him at fault (comperimus) and deposes 9 him (priuauimus). Nicholas is also the one who feels the pain of the returning party 10 (condolentes), seeks to soothe them (consolaremur), yields to the petition of his clergy 11 (condescentes) and grants (concedimus) the pallium. V, in contrast, emphasizes the 12 agency of Ealdred and Tostig while de-emphasizing that of the pope and Roman 13 clergy. Thus, in V's account it is Ealdred who is examined (perscrutatus), and who, 14 after freely admitting wrongdoing, is found (inuentus est) to be at fault and deposed 15 (deiectus). When he returns after the bandit attack, it is not specifically the pope who 16 is empathetic, but the impersonal abstraction "Roman pity" (Romana pietas). Rather 17 than giving way especially (specialiter ac praecipue) to the supplication of Archdeacon

\footnotetext{
${ }^{43}$ quod] om. B

${ }^{44}$ habitu] abitu B

${ }^{45}$ tibi] om. B
} 
1 Hildebrand (the future Gregory VII), the pope in V's account heeds above all (maxi2 me) Earl Tostig's petition and is swayed especially (presertim) by the memory of 3 Ealdred's free confession, and the shame, which he humbly bore, of his deposition. In 4 short, whereas $\mathbf{N}$ underlines the proper and often gracious actions of the pope and 5 clergy, V's focus on Ealdred and Tostig (and omission of Hildebrand) casts them as 6 the protagonists whose virtues and influence ultimately achieve the reversal of their 7 misfortunes.

8 In putting this "spin" on events, $\mathbf{V}$ also omits a detail $\mathbf{N}$ records between sections $\mathrm{i}$ 9 and ii: that the synod, on hearing that Ealdred had moved from Worcester to York not 10 by his own design but at the king's command, reinstated him as bishop of Worcester. 11 One possibility is that $\mathbf{V}$ omitted the detail because it complicated the narrative 12 unnecessarily. Another is that $\mathbf{V}$ did it because it detracted from the narrative of crisis and resolution which the text sought to contrive. The latter possibility fits with use of the construction "non solum ... uerum ab" in place of N's "utraque priuauimus," which underscores the harshness of the papal ruling and elicits sympathy for Ealdred. By omitting to mention that Ealdred had, in fact, been restored to episcopal office, $\mathbf{V}$ is able later to imply that his reinstatement resulted from his humility and the pressure Tostig applied on returning to the papal curia. This reading of V's strategy for revising the narrative in $\mathbf{N}$ fits with his treatment of the Roman clergy in the conclusion. N's clergy petition Nicholas, who yields to their supplication (naming Hildebrand), but in $\mathbf{V}$ it is only after Nicholas is swayed by Tostig and Ealdred that the (nameless) clergy step in with advice that merely confirms his thinking.

The impression that the accounts are in dialogue (or rather that $\mathbf{V}$ revises $\mathbf{N}$, with a view to bringing Ealdred and Tostig to the fore) is reinforced by the discovery, at every step of the narrative, of words and phrases in $\mathbf{V}$ that seem to gloss their similarly positioned counterparts in $\mathbf{N}$. Thus, in the first section, N's tractantes and comperimus prefigure V's perscrutatus and inuentus est, where we may note, in both cases, that Ealdred replaces the pope as the subject. In the same section, $\mathbf{V}$ appears to rephrase N's "sine apostolica auctoritate migrasse" with the formula "commigrasse contra canones." The latter too is a perfect infinitive construction, and its choice of verb seems to be prefigured in N's migrasse. In NVii, Ni's excessively complex “congregatis quamplurimis confratribus coepiscopis nostris Romano synodo presidentes" is reduced in Vii to the simple formula "omni synodo censente," retaining synodo. Vii also looks like it is glossing Nii's "sanctorum patrum statuta" as "apostolicis et pontificalibus decretis." Here too the words dependent on papal agency (the participle sequentes and the finite priuauimus) are converted into passive constructions, sequentes yielding to the ablative absolute decretis examinatis; priuauimus reappearing as deiectus. In NViii the concern displayed by Nicholas and "omnibus Romane ecclesie filiis," who collectively are those condolentes, dissolves into "Romana pietas" which indoluit, 
and so on. Just as migrasse seems to elicit commigrasse, it seems as though N's condolentes has elicited V's indoluit.

As noted earlier, Folcard rewrote his sources thoroughly, even when he had no new perspective to introduce into the narrative. In his Life of St. John of Beverley (VJB), he constantly replaces words and phrases from Bede's text without much altering the meaning. ${ }^{46}$ In rewriting $\mathbf{N}$, the author of $\mathbf{V}$ proceeds in the same fashion, substituting perscrutatus for tractantes, inuentus est for comperimus, episcopio for sede, contra canones for sine apostolica auctoritate ( $\mathbf{V i} ; \mathbf{N i}$ ); examinatis for sequentes (Vii; $\mathbf{N i i})$, and dato for concedimus ( $\mathbf{V v} ; \mathbf{N v})$. No single governing principle appears in either set of substitutions. Sometimes they clarify (e.g. VJB: iussit for praecipiens; inuitatus for uocatus, and V's examinatis for sequentes and dato for concedimus). Often, they render the meaning less clear (e.g. VJB: ancillarum for uirginum; pia mater for abbatissa; pelagi for oceani; rigari for lauaret, and praemortuum for morti proximum; and V's episcopio for sede and contra canones for sine apostolica auctoritate). Given that Folcard's modus convertendi was to treat the substitution of words as an end in itself, as an exercise in glossing, $\mathbf{V}$ clearly behaves as if it were Folcard's reworking of $\mathbf{N}$.

Another feature Folcard's rewriting of Bede shares with his rewriting of the papal letter is the flair both display in substituting pithy summations for prolix clauses. When reworking Bede, for example, Folcard ran into a section where Bede describes how St. John of Beverley tested a mute's ability to speak, after he had been cured. Bede reports:

et loqui illum praecepit, "Dicito," inquiens, "aliquod uerbum; dicito 'gae,"” quod est lingua Anglorum uerbum adfirmandi et consentiendi, id est "etiam." Dixit ille statim, soluto uinculo linguae, quod iussus erat. Addidit episcopus nomina litterarum: "Dicito A"; dixit ille "A". "Dicito B"; dixit ille et hoc. Cumque singula litterarum nomina dicente episcopo responderet, addidit et syllabas ac uerba dicenda illi proponere.

and addressing him, he commanded: "Speak some word; say 'yes," which is the English word for agreeing and consenting, i.e. "indeed." Straight away he said it, as instructed, for his tongue had been unbound. The bishop added the names of letters: "Say A"; he said A. "Say B"; he said this too. And as he repeated the name of each letter

\footnotetext{
${ }^{46}$ Here are sundry examples: remotior for secretior (VJB 4.15; HE v.2.8); frequenter for saepius (VJB 4.14 and 4.25; HE v.2.11 and 19); mento ... comprehendit for adprehendens ... de mento (VJB 4.28; HE v.2.29); peruenit for uenerit (VJB 5.1; HE v.3.5); uicum for loco (VJB 5.1; HE v.3.6); ancillarum for uirginum (VJB 5.3; HE v.3.6); refert for indicauit (VJB 5.5-6; HE v.3.8); pia mater for abbatissa (VJB 5.6; HE v.3.9); magna ... aegritudine for grauissimo languore (VJB 5.7-8; HE v.3.10); precatur for rogauit (VJB 5.9; HE v.3.15); pelagi for oceani (VJB 5.21; HE v.3.23); inuitatus/ inuitatur for uocari/ uocatus (VJB 6.1 and 7.3; HE v.4.8 and v.5.1); iussit for praecipiens (VJB 6.18; HE v.4.19); rigari for lauaret (VJB 6.20; HE v.4.21); subito for statim (VJB 6.20; HE v.4.21); incumbente morbo for acerrima aegritudine (VJB 7.5; HE v.5.3-4); praemortuum for morti proximum (VJB 7.12-13; HE v.5.11), and ille acceptis indumentis uestitur for induit se ipse uestimentis suis (VJB 7.21-22; HE v.5.18-19).
} 
in response to the bishop, he also spoke syllables and words the bishop invited him to say.

Folcard, overwriting this elaborate passage (where the reader begins to dread that the bishop might run through the whole alphabet), summarizes: "Praecedit episcopus, literas quasdam et uerba dicendo; ille qui mutus erat, soluto linguae officio, subsequitur eadem ex ore episcopi loquendo" - "The bishop led by saying certain letters and words; the man who had been mute, now able to speak, repeated everything the bishop said" (HE v.2.31-37; VJB 4.30-32).

In another neat summation, Bede's "signum sanctae crucis linguae eius inpressit" ("he made the sign of holy cross upon his tongue") becomes Folcard's simple "benedixit" ("he blessed") (HE v.2.29-30; VJB 4.28-29). Similarly, where Bede's saint "dixit [more] solito consolantium sermone: 'Bene conualescas et cito"” - "in his usual manner, spoke the comforting words 'now get well soon"), Folcard's saint, with a command more like Christ's, "eum sanari et surgere iussit" - "commanded him to be healed and to arise" (HE v.5.13-14; VJB 7.13-14).

In each of the three instances above, Folcard demonstrates good judgement by dispensing with redundant detail to aid the narrative flow. It is akin to the flair and judgement displayed by the author of the Vita, who also sacrificed detail which he considered unimportant. Niv's long-winded "omnium cardinalium confratrum ac filiorum nostrorum episcoporum uidelicet ac presbyterorum” duly becomes Viv's "Romanis patribus"; and Niii's "tuis cum omnibus Romane ecclesie filiis precordialiter calamitatibus condolentes" becomes Viii's "Romana pietas indoluit." While dispensing with superfluities, however, both rewritings add details from Folcard's own knowledge. Folcard in VJB supplies the location of St. John's oratory, and the Vita adds to the papal letter's account details concerning Ealdred, Tostig and the attack by bandits (VJB 4.12-13, cf. HE v.2. 9-11; and above, NVii).

A more idiosyncratic technique of summation, displayed in both rewritings, corroborates the argument that the same mind was at work in both. It comes to light where the parent texts (whether Bede's or the papal letter) refer to the combined agency of a narrator and others. In such instances, Folcard reduces the complexity of the plural agency by substituting a passive construction that eases the flow of the narrative. In one of Bede's miracle stories in VJB both the founder of a church and the narrator, Berhthun (whose account Bede is relaying) offer to give alms if John accepts the founder's dinner invitation - a pretext for securing the bishop's services in curing his sick wife. Berhthun (quoted by Bede) reports that the insistent founder "uouit etiam se elimosynas pauperibus daturum" - "even promised he would give alms to the poor," and that he, Berhthun, also asked the bishop to join them at dinner and promised to give alms if he attended: "Rogaui et ego una cum illo, promittens etiam me elimosynas ... dare" - "I too asked [the bishop] along with him, promising I too would 
1 give alms." ${ }^{\prime 7}$ Folcard tackles the complex plural agency of first person narration ("et 2 ego una cum illo" - "I too along with him") with an ablative absolute and the passive 3 persuasus, with John as the passive subject: "promissis sub hac gratia eleemosynis 4 pluribus, et maxime Beato Berhtuno idem pollicente persuasus" - "when many alms 5 had been promised on this account, and especially by Blessed Berhthun, [the bishop] 6 was persuaded." ${ }^{\prime 8} \mathrm{He}$ also changes the emphasis, asserting that the pious Berhthun in 7 particular (maxime) swayed the bishop. We see the same kind of shift in NViii, where 8 it is Tostig in particular (again maxime) who sways the pope.

In his passive substitution, the combined agency of the founder and Berhthun in offering to give alms is implied but occluded by a more oblique formula, as Folcard prioritizes brevity over the clarity of additional detail. A close parallel is found in $\mathbf{N V i -}$ ii, where the agency of the narrator, Pope Nicholas, and the assembled clerics is rewritten with an ablative absolute and the passive deiectus, with Ealdred as the passive subject. Ni-ii's "cum eis tractantes ... [et] statuta sequentes, te utraque priuauimus" becomes Vi-ii's "Perscrutatus ... decretis examinatis ... ab episcopatus gradu deiectus," with the ablative absolute clause, as in the previous example, anticipating the passive participle. The agency of the pope and synod is implied but occluded by an oblique formula, as the writer, in this instance too, prioritizes brevity over the clarity achieved by the inclusion of detail. Further examples of this technique of abridgement, with its occlusion of detail found in the parent text, are present in VJB and in $\mathbf{V} .{ }^{49}$ It is worth recalling, here, that the author of the Vita habitually prefers succinctness to the clarity which he could have achieved in both his poetry and his prose if he had allowed himself the leeway to say more. In a rewriter and abridger of texts, that quality is a strength. In an author of original works, where explication is required, the quality is misapplied. It is in this respect that the Vita feels like the work of a writer who was used to summarising things but less well trained in the exposition involved in original composition. ${ }^{50}$

${ }^{47}$ HE v.4. 13-14.

${ }^{48}$ VJB 6.11-12.

${ }^{49}$ In a similar example, Folcard in VJB substitutes another ablative absolute for the complex agency of Bede's narrator and a servant whose words he reports thus: "[the servant/ messenger] clamauit me foras et ait: 'Postulat Quoenburg ... ut ocius regrediaris ad eam [with the bishop]'” becomes: "Petita illa episcopi benedictione" (HE v.3.31-33; VJB 5.31-32). For a similar example in the Vita, compare Nivv's "palleum pontificalis dignitatis ad hoc concedimus" and Viv-v's "et dato palii honore" which rewrites the complex first-person plural with another ablative absolute, while occluding the agency of the pope and synod.

${ }^{50}$ Thus Barlow, despite referring to his prose as "terse and direct." being unadorned and therefore possessing "excellence," could describe it elsewhere as "compact, even crabbed," meaning impenetrable (Vita Ædwardi, ed. Barlow, p. xxvii; see also p. li). There are certainly dense passages which are both direct and difficult to decipher, because they say too little. A more practised stylist would have advised 
As we saw, Folcard's VJB preserves fewer than $10 \%$ of the words used by Bede in the section being rewritten. The figure I calculated was 55 words out of 828 , but the science of converting that into a percentage is not without a little artistry, since some borrowed lexical units are made up of two words in a word chain, while, in other instances, the retention of a word stem may be counted as the retention of a lexical unit if the choice of word was surely inspired by a word in the parent text (migrasse $=$ commigrasse being a good example). The relevant sections from the Vita Ædwardi preserve the following units from Nicholas's letter: commigrasse (Vi; Ni: migrasse); synodo (Vii; Ni); apostolicis (Vii; Ni: apostolica); Romana (Viii; Niii: Romane), indoluit (Viii; Niii condolentes), and pallii (Viv; Niv: pallium). We are justified in seeing these as borrowings from the parent text because they are found at or near each of the same "stepping stones" in the common narrative. It is also worth noting that Ni's uentum esset appears to be the stimulus of inspiration for Vi's inuentus est although the two are not semantically equivalent. If we count the reiterated words and word stems apparently preserved in V's 118 words of reworked material from $\mathbf{N}$, we arrive at 7/118. This converts into 5.9\%, which is surprisingly close to the 6.6\% (55/828) discovered in the larger sample provided by the reworked passages of $V J B$. Both rewritings retain words only where there was no better alternative (e.g. in VJB orationibus, mutus, sententiae, capitis, in quarta luna; and in V synodo, apostolicis, Romana, and pallii).

There are, finally, a couple of minor points to be made concerning vocabulary. Folcard liked to use pius and pietas in his writing. He also liked to insert them when rewriting texts, even where it seems that nothing in the parent text would give rise to their insertion. In one miracle, we find pia mater for Bede's abbatissa, and "in Dei pietate" (referring to no word supplied by Bede); in another, there is a reference to the "pio presuli" John, where again the adjective is Folcard's addition. ${ }^{51}$ The same phenomenon is found in Viii where the empathy of the pope and Roman clergy becomes "Romana pietas." The second observation is that the verb commigro, which Vi substitutes for Ni's migro (likewise in the passive infinitive), is a rare word that was used by Folcard elsewhere. Bede employs it in his De temporum ratione to describe the movement of the sun; and Folcard employs it in VJB, likewise to describe the sun's passage ("sol illuc commigrasset"). ${ }^{52}$

the author to unpack or explain his remarks at such points. The quality of the poetry obtains in its layering of meaning and dexterous shifting allusions, but there is not much variety of rhythm or metre, the metrics are rather cavalier, and the polish is inconsistent. In some of the Vita's poems, there is a prevalence of end-stopped lines and shortage of polysyllabic words that span more than one foot. In others, the author achieves greater fluency and variation.

${ }^{51}$ VJB 5.6 and 10; and 6.25; cf. HE v.3.9 and 16; and v.4.23.

${ }^{52}$ DMLBS, Fasc. II:C, prepared by Robert E. Latham (London, 1981), p. 393, citing Bede, De temporum ratione, 35: "ut ... [sol] per diuersa commigrans terrenis fructibus ... temperamenta custodiat." See VJB 11.21 (p. 258). 


\section{Conclusion}

2 At the beginning of this article I signalled my intention to argue that the Vita's ac-

3 count of the English delegation to Rome in 1061 was neither an independent record

4 (independent, that is, of the account given in Nicholas's letter) nor an account deriv-

5 ing from it at one remove via an unidentified lost text. It is time now finally to dis-

6 pense with those hypotheses. The account in the Vita is unlikely to be entirely

7 independent, because it is structured in a very similar way and makes similar points,

8 with the same or similar vocabulary, at each step of the narrative. It also appears to be

9 in dialogue with Nicholas's letter, in that it downplays the role of the pope, shifts the

10 emphasis to Tostig and Ealdred, and substitutes their persuasive powers for those of 11 Archdeacon Hildebrand.

It is also highly unlikely that the account in the Vita derives from that in Nicholas's letter at one remove, via a lost source. Occam's razor, for a start, might leave us disinclined to posit that hypothesis, but what we now know about Folcard's techniques of rewriting might prompt us to dismiss it altogether. In a work prepared for Ealdred in the 1060s (that is to say VJB), he rewrote the parent text thoroughly, treated the task almost as an exercise in glossing - finding suitable synonyms - and employed distinctive techniques for simplifying his material. One of them was to resolve convoluted detail into pithy summations which nevertheless rendered the detail a little opaque. Another was to convert plural first-person agency (where more than one person were the subject of the sentence) into passive constructions, with the ablative absolute. Finally, he preserved about $6 \%$ of the words and word stems of his Bedan parent text. All the features just described apply to $\mathbf{V}$ if it is correctly identified as a rewriting of $\mathbf{N}$. $\mathbf{V}$ behaves in other words exactly as it should were it Folcard's rewriting of the version in Nicholas's letter. The shift of interest away from the Roman clergy in favour of Ealdred and Tostig aligns with Folcard's sympathies, and we know that he could have had access to the papal letter as one of the clerics of Ealdred's household. Since there are very strong reasons in any case for identifying Folcard as the author of the Vita, it is safe to conclude that $\mathbf{V}$ is his rewriting of the letter.

Last, we must turn to the opening of the Vita, in which the author recounts his recent hardships in terms which continue to mystify interpreters. Referring to himself, he declares: "And I, poor me, all ruined now, lack much," adding that Edith had in pity "reached out, and made me stand lest I fall again"; that she had restored him "as from death," and that he owed his life to her, concluding "as long as she lives, I shall surely survive." ${ }^{53}$ The indications are that he had escaped a dire predicament. The constellation Libra is ascendant as he writes, he tells us, placing the inception of his work be${ }^{53}$ Vita Edwardi, ed. Barlow, pp. 3, 5 and 4 (“dum uiuit, certe uiuimus”); see pp. lvii-lviii for Barlow's
discussion. 
1 tween late September and late October. ${ }^{54}$ The $\mathrm{C}$ text of the Anglo-Saxon Chronicle 2 offers a clue here by reporting that the northern rebellion, which occurred in King Ed3 ward's last year, began in York as an assault upon Earl Tostig's household after 4 Michaelmas (29 Sep) 1065. The Vita's remarks could be those of a refugee who had 5 fled to the royal court and sought Edith's protection after the destruction or loss of his 6 livelihood ("rebus dilapsis"). ${ }^{55}$ Could it be the case, then, that Folcard fled south and 7 was writing at a place of refuge? Wilton is a strong possibility, as Elizabeth Tyler has 8 suggested, not only because Edith regarded it as a special abode and because the au9 thor includes a poem in its honour, but also because it was close to Britford, where the 10 king and Tostig were when news of the rebellion broke. ${ }^{56}$ High-status fugitives with 11 access to the court would have fled straight there, as Eustace of Boulogne did in 1051, 12 when he fled fighting in Dover and rode straight to the king at Gloucester. ${ }^{57}$ The other 13 possibility is that the fugitive then moved with the court, as his detailed description of 14 the building work at Westminster suggests. Barlow's opinion that he began writing in 15 the autumn of 1065 has recently been upheld and reinforced with new literary and 16 historical arguments, so the chronology fits the outline as proposed. ${ }^{58}$ Edith had sent 17 Folcard to Ealdred in the first place. It follows that he was, ultimately, under the 18 queen's protection; that he would properly have fled to her had he been dislodged by 19 the northern rebellion of 1065 (as well he might, as an avowed friend of Tostig); and 20 that Edith was bound to provide for him when Ealdred no longer could. ${ }^{59}$

\section{ABSTRACT}

22 This article argues that the account of the English diplomatic mission to Rome in 1061, which 23 appears in the Vita Edwardi regis, is modelled on the account in Pope Nicholas II's letter to Archbishop Ealdred of York. Rejecting the hypothesis that the two accounts could be

${ }^{54}$ Vita Adwardi, ed. Barlow, p. 3, n. 3.

55 "Nos tenues, rebus dilapsis, pluris egemus" - "A pauper, having lost my possessions, I am much in need." Here I restore the punctuation found in the manuscript: London, British Library, MS Harley 526, fol. 38r. Compare Vita ÆEdwardi, ed. Barlow, pp. $2 / 3$.

${ }^{56}$ Britford was the nearest place to where the king was hunting when news of the rebellion came: Vita Ædwardi, ed. Barlow, p. 78; Anglo-Saxon Chronicle C 1065. On placing the composition of the work at Wilton, see Tyler, England in Europe, pp. 203-7 and 251, n. 213.

${ }^{57}$ Anglo-Saxon Chronicle D 1051.

${ }^{58}$ Licence, “The Date and Authorship,” pp. 260-72; Tyler, England in Europe, pp. 135-44, concluding (p. 144): "If we do not accept the reality of the text's real-time narration, then we need to come up with compelling reasons that the Anonymous created this fiction (which he maintains without a slip) and that, when he is so interested in the nature of fiction, he does not characterize this aspect of his narrative as fictional."

${ }^{59}$ For Barlow's groundwork, see Vita Ædwardi, pp. lii-lvi. 
independent or related at one remove, it demonstrates that the Vita's account of the mission retains the narrative framework provided by the letter. It also shows that it shifts the political emphasis and reworks the parent text in ways Folcard of St. Bertin (the author of the Vita) is known to have reworked Bede's account of St John of Beverley. The discovery sheds light on Folcard's sources for the Vita and on his techniques in reworking Latin narrative.

\section{RÉSUMÉ}

7 Cet article soutient que le récit de la mission diplomatique anglaise à Rome de 1061, qui 8 apparaît dans la Vita ÆEdwardi regis, est modelé sur celui qu'on trouve dans la lettre du Pape 9 Nicolas II à l'archevêque Ealdred d'York. Rejetant l'hypothèse selon laquelle les deux récits 10 seraient indépendants l'un de l'autre ou bien reliés au second degré, nous démontrons que le récit de la Vita préserve le cadre narratif pourvu par la lettre. De plus nous mettons en évidence que le récit détourne l'angle politique et retravaille le texte parent d'une façon évoquant celle dont, on le sait, Folcard de Saint-Bertin (l'auteur de la Vita) a fait usage pour reprendre 14 le récit de Bède sur saint Jean de Beverley. Cette découverte jette la lumière sur les sources de 15 Folcard pour la Vita et sur les techniques qu'il employait en retravaillant des récits latins.

16 
